\title{
Notes
}

\section{A Nineteenth Amendment Defense of the Violence Against Women Act}

\author{
Sarah B. Lawsky
}

\section{INTRODUCTION}

In 1993, over half a million American women were raped.' A quarter of those women were raped by an intimate: a husband or ex-husband, a boyfriend or ex-boyfriend. ${ }^{2}$ Women in America are six times more likely than men to be the victim of a violent crime committed by an intimate, ${ }^{3}$ and women are more likely to be injured in violent incidents committed by intimates than in incidents committed by strangers. Violence is the leading cause of injuries to American women ages fifteen to forty-four, more common than car accidents, muggings, and cancer deaths combined. ${ }^{5}$ Four million American women are the victims of domestic violence each year. ${ }^{6}$ Three-quarters of American women will be victims of violent crimes sometime during their lives. ${ }^{7}$

Faced with such facts, Congress passed the Violence Against Women Act (VAWA) in $1994 .^{8}$ The many provisions of the Act were intended, as the Act's name suggests, to respond to "the escalating problem of violence

1. See Ronet Bachman \& Linda E. Saltzman, U.S. Dep't of Justice, Violence AGAINST WOMEN 2 (1995).

2. See id. at 3.

3. See S. REP. NO. 103-138, at 38 (1993); see also BACHMAN \& SALTZMAN, supra note 1, at 3.

4. See BACHMAN \& SALTZMAN, supra note 1 , at 5.

5. See S. REP. No. 103-138, at 38.

6. See id.

7. See id.

8. Pub. L. No. 103-322, 108 Stat. 1902 (1994). 
against women." 9 Some of these provisions are uncontroversial; certainly, nobody would question Congress's power to provide, as the Act does, extensive federal funding to states to help states discourage violence against women. ${ }^{10}$ Other parts of the Act have been challenged as unconstitutional but have never been struck down by any court and seem clearly to be valid exercises of congressional power. For example, courts have repeatedly upheld as a valid exercise of Congress's power under the Commerce Clause $^{11}$ those sections of the Act $^{12}$ that make it a federal crime to commit domestic violence or to violate a protective order after crossing state lines with the intention to commit such an act. ${ }^{13}$

The Act also creates a federal civil rights remedy for victims of gendermotivated violence. ${ }^{14}$ This provision's constitutionality is much less clear.

\footnotetext{
9. S. REP. No. 103-138, at 37.

10. See, e.g., 42 U.S.C. $\$ \S 300 \mathrm{w}-10.3796 \mathrm{gg}, 10402$ (a) (1994).

11. U.S. CONST. art. I, $\S 8$.

12. 18 U.S.C. $\$ \$ 2261-2262(1994)$.

13. See, e.g., United States v. Page, 167 F.3d 325 (6th Cir. 1999) (en banc) (affirming by an evenly split court a conviction under § 2261); United States v. Gluzman, 154 F.3d 49 (2d Cir. 1998), cert. denied, 119 S. Ct. 1257 (1999); United States v. Bailey, 112 F.3d 758 (4th Cir. 1997); United States v. Frank, 8 F. Supp. 2d 253 (S.D.N.Y. 1998). The provision of the Act that prohibits possession of a firearm while under a domestic-violence restraining order, 18 U.S.C. $\$ 922(\mathrm{~g})(8)$. has also been challenged, and one court has held that that provision violates the Second Amendment. See United States v. Emerson, 46 F. Supp. 2d 598 (N.D. Tex. 1999). However, every other court that has considered $\S 922(\mathrm{~g})(8)$ has found it to be constitutional. See, e.g. . United States v. Myers, No. 98-2560, 1999 WL 475571 (8th Cir. June 29, 1999) (rejecting Tenth Amendment and Commerce Clause challenges to $\S 922(\mathrm{~g})(8)$ ); United States v. Meade, 175 F.3d 215 (1st Cir. 1999) (rejecting Fifth and Tenth Amendment challenges); United States v. Bostic. 168 F.3d 718 (4th Cir. 1999) (rejecting Fifth and Tenth Amendment and Commerce Clause challenges); United States v. Cunningham, 161 F.3d 1343 (I lth Cir. 1998) (rejecting a Commerce Clause challenge); United States v. Wilson, 159 F.3d 280 (7th Cir. 1998) (rejecting Fifth and Tenth Amendment and Commerce Clause claims), cert. denied, 119 S. Ct. 2371 (1999); United States v. Pierson, 139 F.3d 501 (5th Cir. 1998) (rejecting a Commerce Clause challenge): United States v. Henson, 55 F. Supp. 2d 528 (S.D. W. Va. 1999) (explicitly rejecting holdıng in Emerson); United States v. Boyd, 52 F. Supp. 2d 1233 (D. Kan. 1999) (rejectung Commerce Clause, Ex Post Facto Clause, and Second and Fifth Amendment challenges).
}

14. This section provides in full:

$\S 13981$. Civil rights

(a) Purpose

Pursuant to the affirmative power of Congress to enact this part under section 5 of the Fourteenth Amendment to the Constitution, as well as under section 8 of Article I of the Constitution, it is the purpose of this part to protect the civil rights of victims of gender motivated violence and to promote public safety, health, and activities affecting interstate commerce by establishing a Federal civil rights cause of action for victims of crimes of violence motivated by gender.

(b) Right to be free from crimes of violence All persons within the United States shall have the right to be free from crimes of violence motivated by gender (as defined in subsection (d) of this section).

(c) Cause of action

A person (including a person who acts under color of any statute, ordinance. regulation, custom, or usage of any State) who commits a crime of violence motivated by gender and thus deprives another of the right declared in subsection (b) of this section shall be liable to the party injured, in an action for the recovery of 
Most courts that have faced the question of $\S 13981$ 's constitutionality have ruled that it is a valid enactment under Congress's Commerce Clause powers. ${ }^{15}$ However, the Fourth Circuit and at least one federal district court have held that the civil rights provision of VAWA is not a valid exercise of congressional power under either the Commerce Clause or the Fourteenth Amendment. ${ }^{16}$

compensatory and punitive damages, injunctive and declaratory relief, and such other relief as a court may deem appropriate.

(d) Definitions

For purposes of this section-

(1) the term "crime of violence motivated by gender" means a crime of violence committed because of gender or on the basis of gender, and due, at least in part. to an animus based on the victim's gender, and

(2) the term "crime of violence" means-

(A) an act or series of acts that would constitute a felony against the person or that would constitute a felony against property if the conduct presents a serious risk of physical injury to another, and that would come within the meaning of State or Federal offenses described in section 16 of title 18 , whether or not those acts have actually resulted in criminal charges. prosecution, or conviction and whether or not those acts were committed in the special maritime, territorial, or prison jurisdiction of the United States: and

(B) includes an act or series of acts that would constitute a felony described in subparagraph (A) but for the relationship between the person who takes such action and the individual against whom such action is taken.

(e) Limitation and procedures

(1) Limitation

Nothing in this section entitles a person to a cause of action under subsection (c) of this section for random acts of violence unrelated to gender or for acts that cannot be demonstrated, by a preponderance of the evidence, to be motivated by gender (within the meaning of subsection (d) of this section).

(2) No prior criminal action Nothing in this section requires a prior criminal complaint, prosecution, or conviction to establish the elements of a cause of action under subscction (c) of this section.

(3) Concurrent jurisdiction

The Federal and State courts shall have concurrent jurisdiction over actions brought pursuant to this part.

(4) Supplemental jurisdiction Neither section 1367 of title 28 nor subsection (c) of this section shall be construed, by reason of a claim arising under such subsection, to confer on the courts of the United States jurisdiction over any State law claim seeking the establishment of a divorce, alimony, equitable distribution of marital property, or child custody decree.

42 U.S.C. § 13981.

15. See, e.g., Doe v. Mercer, 37 F. Supp. $2 d 64$ (D. Mass. 1999); Liu v. Striuli. 36 F. Supp. 2d 452 (D.R.I. 1999); Mattison v. Click Corp. of Am., Civ. A. No. 97-CV-2736. 1998 IVL 32597 (E.D. Pa. July 27, 1998); Ziegler v. Ziegler. 28 F. Supp. 2d 601 (E.D. Wash. 1998); Crisonino v. New York City Hous. Auth., 985 F. Supp. 385 (S.D.N.Y. 1997): Anisimov v. Lake. 982 F. Supp. 531 (N.D. III. 1997); Seaton v. Seaton, 971 F. Supp. 1188 (E.D. Tenn. 1997): Doc v. Hartz, 970 F. Supp. 1375 (N.D. Iowa 1997), rev'd on other grounds, 134 F.3d 1339 (8th Cir. 1998); Doe v. Doe, 929 F. Supp. 608 (D. Conn. 1996).

16. See Brzonkala v. Virginia Polytechnic Inst. \& State Univ., 169 F.3d 820 (4th Cir. 1999) (en banc), cert. granted, 68 U.S.L.W. 3021 (U.S. Sept. 28. 1999) (Nos. 99-5, 99-29): Bergeron v. Bergeron, 48 F. Supp. 2d 628 (M.D. La. 1999) (following the reasoning of, and reaching the same conclusion as, Brzonkala). 
In this Note, I argue that the civil rights provision of VAWA is a valid enactment under the Nineteenth Amendment, which granted women suffrage. Part II demonstrates that the Nineteenth Amendment is about more than voting alone; the Nineteenth Amendment also forbids the state from interfering with women's political citizenship and full political participation. Next, in Part III, I argue that a culture of violence against women interferes with women's rights to be political citizens. For a person to be a political citizen, she must be able to participate, free from domination, as a self-determined equal, in the deliberation that is essential to a republican form of government. But self-determination and equality are difficult, if not impossible, in the face of an omnipresent threat of violence. A culture of violence against women therefore interferes with women's ability to participate fully in political life. Part IV sketches out the specific requirements for congressional action under the Nineteenth Amendmentthat the legislation must be remedial and that the state must play a role in the constitutional violation to be remedied-and establishes that VAWA fulfills these requirements. In particular, I argue that the state helps create a culture of violence against women because the state creates marriage, which, when viewed in historical context, is shown to be an institution that perpetuates women's subordination and violence against women. I conclude that VAWA is valid legislation under the Nineteenth Amendment.

\section{THE MEANING OF THE NINETEENTH AMENDMENT}

The Nineteenth Amendment ${ }^{17}$ means both less and more than is commonly thought. It means less in that it guarantees nobody the right to vote; instead, it ensures only that the state will not interfere with the right to vote because of a voter's gender. But it means more because it is, at its heart, about more than merely the right to vote: It is about the right to be a full political citizen. And in a country with republican roots, like ours, being a full citizen means being an uncoerced participant in the country's political deliberation.

The Nineteenth Amendment does not confer upon women a constitutionally protected right to vote; it does, however, forbid interference with the voting right on the basis of the gender of the qualified voter. The Constitution "does not confer the right of suffrage upon any one." 18 The

17. U.S. CONST. amend. XIX ("The right of citizens of the United States to vote shall not be denied or abridged by the United States or by any State on account of sex. Congress shall have power to enforce the article by appropriate legislation.").

18. Minor v. Happersett, 88 U.S. (21 Wall.) 162, 178 (1875); see also, e.g., San Antonio Indep. Sch. Dist. v. Rodriguez, 411 U.S. 1, 35 n.78 (1973) ("[T]he right to vote, per se, is not a constitutionally protected right...."); United States v. Reese, 92 U.S. 214, 217 (1876) ("The Fifteenth Amendment does not confer the right of suffrage upon any one."). But $c f$. Reynolds v. 
right to vote is a right conferred by states, ${ }^{19}$ it is the state that determines who will vote in federal elections. ${ }^{20}$ States may set certain limits on the franchise. For example, a state may constitutionally prohibit a person from voting if she fails to pass a literacy test. ${ }^{21}$ But there are constitutional limitations on a state's ability to deny the right to vote..$^{22}$ The Constitution tells us, for example, that an otherwise qualified voter may not be turned away from the polls merely because she is black ${ }^{23}$ or because she is nineteen years old. ${ }^{24}$ The Nineteenth Amendment is one such limitation. While the Nineteenth Amendment does not actually confer the right to vote on any particular woman, no woman (or man) may be denied the right to vote simply because of her (or his) gender.

To understand the full meaning of the Nineteenth Amendment, however, it is necessary to look beyond the plain text of the amendment to the historical and political context in which the amendment was produced. ${ }^{25}$ This task is complicated by the fact that the vote had no single meaning to the suffragists. As Aileen Kraditor states, "The woman suffrage movement had no official ideology. Its members and leaders held every conceivable

Sims, 377 U.S. 533, 554 (1964) ("Undeniably the Constitution of the United States protects the right of all qualified citizens to vote, in state as well as in federal elections.").

19. See, e.g., Lassiter v. Northampton County Bd. of Elections, 360 U.S. 45, 51 (1959) ("While... the Fourteenth Amendment... speaks of 'the right to vote, the right protected 'refers to the right to vote as established by the laws and constitution of the State."' (citation omitted)); Pope v. Williams, 193 U.S. 621, 632 (1904) ("The privilege to vote in any State is not given by the Federal Constitution, or by any of its amendments. It is not a privilege springing from citizenship of the United States.... [T] he privilege to vote in a State is within the jurisdiction of the State itself, to be exercised as the State may direct, and upon such terms as to it may seem proper ...."), overruled on other grounds by Dunn v. Blumstein, 405 U.S. 330 (1972); overruling recognized by Payne v. Tennessee, 501 U.S. 808, 828 n.l (1991).

20. See U.S. CONST. art. I, § 2; id. amend. XVII.

21. See Lassiter, 360 U.S. 45.

22. See, e.g., Breedlove v. Suttles, 302 U.S. 277, 283 (1937) ("Privilege of voting is not derived from the United States, but is conferred by the State and, save as restrained by the Fifteenth and Nineteenth Amendments and other provisions of the Federal Constitution, the State may condition suffrage as it deems appropriate." (emphasis added)), overnuled on other grounds by U.S. CONST. amend. XXIV; Pope, 193 U.S. at 633 ("[T]he conditions under which that right [to vote] is to be exercised are matters for the states alone to prescribe, subject to the conditions of the Federal Constitution...." (emphasis added)); McPherson v. Blacker, 146 U.S. 1, 38 (1892) ("The Fifteenth Amendment exempted citizens of the United States from discrimination in the exercise of the elective franchise on account of race, color or previous condition of servitude. The right to vote in the States comes from the States, but the right of exemption from the prohibited discrimination comes from the United States. The first has not been granted or secured by the Constitution of the United States, but the last has been."); cf. San Antonio Indep. Sch. Dist., 411 U.S. at $35 \mathrm{n} .78$ (" [There is a] protected right, implicit in our constitutional system, to participate in state elections on an equal basis with other qualified voters ....").

23. See U.S. CONST. amend. XV.

24. See U.S. CONST. amend. XXVI.

25. For another argument that, given proper atuention to history, the Ninetcenth Amendment is best read as "a constitutional commitment to rectify [the] history of [women's] subordination." see Reva Siegel, Collective Memory and the Nineteenth Amendment: Reasoning About "the Woman Question" in the Discourse of Sex Discrimination, in HISTORY, MENIORY, AND THE LAW 131, 132 (Austin Sarat \& Thomas Kearns eds., 1999). 
view of current events and represented every philosophical position." ${ }^{26}$ It is safe to say, however, that one part of the suffragists' vision encompassed republican values and ideology. After a brief review of the meaning of republicanism, I look at some of the ways that republicanism manifested itself in the arguments of the woman suffrage ${ }^{27}$ movement. I then examine republicanism as recently revived by a variety of scholars.

Defining republicanism is no simple task. Indeed, it was John Adams's opinion that " $[t]$ here is not a more unintelligible word in the English language than republicanism." ${ }^{28}$ There are, however, a few themes that appear repeatedly in the literature about republicanism. According to republican views, suffrage comprised a package of political rights, including the right to serve on a jury and the right to hold office. ${ }^{29}$ Suffrage, that is, conferred the right to full citizenship, which meant active participation in the political community. ${ }^{30}$ This active participation was considered a good in itself. ${ }^{31}$ Traditional republicanism also emphasized the common good over individual self-interest,$^{32}$ and held that to participate in

26. AILEEN S. KRAditor, THE IdEAS OF THE WOMAN SUFFRAGE MOVEMENT 1890-1920, at xi (1981).

27. Suffragists referred to "woman suffrage," not "women's suffrage." For a brief discussion of the term "woman suffrage," see JoEllen Lind, Dominance and Democracy: The Legacy of Woman Suffrage for the Voting Right, 5 UCLA WOMEN's L.J. 103, 105 n.4 (1994).

28. Letter from John Adams to Mercy Otis Warren (Aug. 8, 1807), quoted in LiNDA K. KERBER, TOWARD AN INTELLECTUAL HISTORY OF WOMEN 131 (1997).

29. See Akhil Reed Amar, Women and the Constitution, 18 HARV. J.L. \& PUB. POL'Y 465 , 467-68 (1995) [hereinafter Amar, Women and the Constitution]; Vikram David Amar. Jury Service as Political Participation Akin to Voting, 80 CORNELL L. REV. 203, 205 (1995) [hereinafter Amar, Jury Service]; see also Richard A. Primus, Canon, Anti-Canon. and Judicial Dissent, 48 DUKE L.J. 243, 290 (1998) ("According to Akhil Amar's thick theory of Reconstruction rights, the category of political rights encompassed all the rights associated with the republican tradition of political citizenship, including not just suffrage and officeholding but also the right to sit on juries and the right to serve in the military." (emphasis added)). Mark Tushnet takes a slightly different view. While he acknowledges the importance of the distinction between civil and political rights, and states that it was clear to those in the nineteenth century that "[p]olitical rights included voting," he argues that "[t]here was some controversy over what other rights were political." Mark Tushnet, The Politics of Equality in Constitutional Law: The Equal Protection Clause, Dr. Du Bois, and Charles Hamilton Houston, 74 J. AM. Hist. 884, 887 (1987). For example, some argued that sitting on juries was a civil right, while others claimed that it was a political right. See id. For an in-depth discussion of the historical basis of the distinction between civil and political rights, see AKHIL REED AMAR, THE BILL OF RIGHTS 216-18 \& 217 n.*. 258-66 $\& 260$ n.* (1998).

30. $C f$. Judith N. ShKlar, American Citizenship: The Quest for InClusion (1991). Shklar believes that the ballot is "a certificate of full membership in society." Id. at 2 . However. according to Shklar, although political citizenship is a badge of full citizenship, political citizenship is not sufficient for someone actually to be a "recognized and active citizen." $l d$. at 64 . One must also be independent-that is, an "earner," one who is paid for the work he has done. See id. This is fully consistent with the republican belief, discussed below, that a certain amount of property was necessary for independence and full political participation. See infra text accompanying note 75 .

31. See, e.g., Linda K. Kerber, Making Republicanism Useful, 97 YALE L.J. 1663, 1663 (1988).

32. See, e.g., KERBER, supra note 28 , at 136-37 (citing Gordon Wood and J.G.A. Pocock): Nomi Maya Stoltzenberg, A Book of Laughter and Forgetting: Kalman's "Strange Career" and 
the political community, a person must possess civic virtue-that is, the ability to work for the public good instead of merely for one's own private ends. ${ }^{33}$ Those who did not possess civic virtue, which was the key to effective participation (and hence to effective government), could not be full political citizens. ${ }^{34}$

The woman suffrage movement used each of these themes to argue for the ballot for women. For example, the suffragists were well aware of the "packaged" nature of political rights. ${ }^{35}$ As one delegate to the 1852 Syracuse National Woman's Rights Convention, J. Elizabeth Jones, proclaimed, the right to vote "includes all other rights. I want to go into the Legislative Hall, sit on the Judicial Bench, and fill the Executive Chair." 36 Jones saw the ability to vote and the ability to hold office as linked. Similarly, in an 1867 speech at the Constitutional Convention of New York, George William Curtis responded to arguments that if women were to vote, then they would also have the right to sit on juries, hold office, and perform military service, not by denying the connection between voting and these rights and responsibilities, but rather by agreeing with each proposition and arguing that women were suited to perform each duty. ${ }^{37}$

Both suffragists' and anti-suffragists' visions of woman suffrage went well beyond political rights, however. Some suffragists had an allencompassing view of the right to vote; they saw the ballot as "the symbol and guarantee of all other rights," 38 and "the symbol of Equality for Woman." 39 This was not an outlandish view: Soon after the Nineteenth Amendment was ratified, a conservative Supreme Court similarly suggested

the Marketing of Civic Republicanism, 111 HARV. L. REV. 1025. 1026 (1998) (reviewing LAURA Kalman, THE StRANGE CAREER OF LeGal LiberalisM (1996)).

33. See, e.g., Isaac Kramnick, Republican Revisionism Revisiled. 87 AM. HIST. REV. 629. 630 (1982) (describing the virtuous republican man as "concerned primarily with the public good, ... not with private or selfish ends").

34. See KERBER, supra note 28, at 136-37.

35. Mark Tushnet claims that "[t]he adoption of the Fifteenth Amendment essentially eliminated the need to distinguish between civil and political rights." Tushnet, supra note 29. at 887. However, while the distinction may have become less important or even irrelevant for men after both the Fourteenth and Fifteenth Amendments were ratified and all men were granted both civil and political rights, for women. who were not enfranchised by the Fiftenth Amendment. the distinction between political and civil rights still loomed large.

36. J. Elizabeth Jones, Address at Syracuse National Convention (Sept. 8-10, 1852). in THE CONCISE History of WOMAN SufFrage 129, 129 (Mari Jo Buhle \& Paul Buhle eds., 1978) [hereinafter CONCISE HISTORY].

37. See GeORge Willlam CuRtis, EQual Rights for WOMEN 17, 18, 21 -22 (New York. American Equal Rights Ass'n 1867).

38. Resolutions of the SEVENTH National WOAiaN's RIGHTS CONVENTION IN NEW YORK (1856), reprinted in PUBLIC WOMEN, PUBLIC WORDS: A DOCUMENTARY HISTORY OF AMERICAN FEMINISM 219, 220 (Dawn Keetley \& John Penegrew eds.. 1997) [hereinafter PUBLIC WOMEN].

39. Political Organization, WOMAN's J., Jan. 8, 1870, reprinted in PUBLIC WOMEN, supra note 38 , at $253,254$. 
that the amendment could be read as ratifying true equality for women. In striking down a minimum wage law for women, the Court wrote,

In view of the great-not to say revolutionary-changes which have taken place ... in the contractual, political, and civil status of women, culminating in the Nineteenth Amendment, it is not unreasonable to say that these differences [between men and women] have now come almost, if not quite, to the vanishing point. ${ }^{40}$

More narrowly, suffragists believed the vote would allow women to participate, as full citizens, in community life. Women were of course citizens before the Nineteenth Amendment, but, as the Supreme Court had announced in 1874, women were not full, political citizens. That is, while women were "citizen[s] from . . . birth, and entitled to all the privileges and immunities of citizenship," ${ }^{41}$ their citizenship did not include the right to vote. $^{42}$ Suffragists were determined to move beyond this second-class citizenship, ${ }^{43}$ referring to the ballot as providing "political recognition" ${ }^{44}$ and "political equality." ${ }^{45}$ The political equality imagined by the suffragists involved full and equal participation in the public sphere. ${ }^{46}$ As Jane Addams argued, the ballot would provide women with "natural participation in civic life." ${ }^{47}$ Suffragists believed that the ballot would take women out of the private sphere of the family and make them "member[s] of the community." 48

While the suffragists welcomed the upheaval they thought would accompany the vote, the anti-suffrage movement dreaded the revolutionary

40. Adkins v. Children's Hosp., 261 U.S. 525, 553 (1923), overruled on other grounds by West Coast Hotel Co. v. Parrish, 300 U.S. 379 (1937). (Justice Holmes dissented in Adkins. famously - and perhaps a bit grumpily - proclaiming that "[i]t will need more than the Nineteenth Amendment to convince me that there are no differences between men and women." $l d$. at 569 . 70.) The Court has not put Adkins's broad vision of the Nineteenth Amendment to further use.

41. Minor v. Happersett, 88 U.S. (21 Wall.) 162, 170 (1875).

42. See id. at 170-78.

43. See generally Rogers M. Smith, "One United People": Second-Class Female Citizenship and the American Quest for Community, 1 YALE J.L. \& HUMAN. 229 (1989) (tracing the development of women's citizenship from the colonial era to the present).

44. Stephen S. Foster, Statement at the 1866 Woman's Rights Convention (May 10, 1866), in CONCISE HISTORY, supra note 36, at 230, 231.

45. E.g., VICTORIA WOODHULl, MEMORIAL AND PETITION TO THE JUdiCIARY COMMITTEE OF THE HOUSE OF REPRESENTATIVES (Dec. 19, 1870 \& Jan. 11, 1871), reprinted in CONCISE HISTORY, supra note 36, at 283, 286; NATTONAL WOMAN SUFFRAGE ASS'N, APPEAL AND PETITION FOR A SIXTEENTH AMENDMENT (Nov. 10, 1876), reprinted in CONCISE History, supra note 36 , at 304,306 .

46. See Ellen Carol DuBois, Woman SufFrage and Women's Rights 36-37 (1998).

47. Jane Addams, The Modern City and the Municipal Franchise for Women, Address Before the NAWSA Convention (Feb. 7-13, 1906), in CONCISE HISTORY, supra note 36, at 371, 371.

48. Charlotte Perkins Stetson [later Gilman], The Ballot as an Improver of Motherhood, Address Before the NAWSA Convention (Jan. 23-28, 1896), in CONCISE HISTORY. supra note 36. at $363,363$. 
potential of granting women the vote, fearing that it would destroy the family. ${ }^{49}$ To anti-suffragists, the basic unit of society was the family, not the individual. $^{50}$ The husband served as the sole political representative of the family. Because granting women the vote would allow them to be political citizens, no longer represented by their husbands, woman suffrage would "dissolve society into a heterogeneous mass of separate persons, whose individual rather than family interests would thenceforth receive political representation." ${ }^{51}$ Historically, then, the Nineteenth Amendment is "fundamentally about women's political participation." 52 This is consistent with the republican idea that being a political citizen means more than just casting a vote; it means active deliberation and participation in civic life.

Suffragists also emphasized the republican notions of the importance of the common good and of the virtue of political participants. Aileen Kraditor has argued that there were two main kinds of arguments for woman suffrage: arguments from justice and arguments from expediency. 33 " Under the term expediency are subsumed arguments that claim that woman suffrage would benefit society," she explains. ${ }^{54}$ These arguments stressed "the ways in which [women] differed from men, and therefore had the dutty to contribute their special skills and experience to government." ss As Clarina Howard Nichols, a delegate to the 1852 Syracuse Convention, put it, "Woman must seek influence, independence, representation, that she may have power to aid in the elevation of the human race.... [T] strongest reason why woman should seek a more elevated position, is because her moral susceptibilities are greater than those of man." s6 Arguments from expediency, then, are essentially arguments that women should be granted the vote for the sake of the country.

The suffragists also argued, again consistently with republican ideology, that because virtue was necessary for participation in public life, there should not be universal suffrage..$^{57}$ Many suffragists, most notably

49. See Ellen Carol Dubois, Feminism and Suffrage: THE EMIERgence of an INDEPENDENT WOMEN'S MOVEMENT IN AMERICA 1848-1869. at 46-47 (1978).

50. See KRADITOR, supra note 26 , at 24.

51. Id at 25. For an example of an anti-suffragist evoking the specter of the destruction of the family, see Arguments Before the Committee on Privileges and Elections of the United States Senate in Behalf of a Sixteenth Amendment to the Constitution of the United States, Prohibiting the Several States from Disfranchising United States Citizens on Accounl of Sex, 45th Cong. 44 (1878) (statement of Madeleine Vinton Dahlgren).

52. Amar, Women and the Constitution, supra note 29, at 473.

53. See KRADITOR, supra note 26 , at $43-74$.

54. Id. at $45 \mathrm{n} .1$.

55. Id at 66; see also DUBols, supra note 46, at 94-98 (discussing the shift from universal suffrage arguments to arguments emphasizing the fundamental differences between women and men).

56. Clarina Howard Nichols, Remarks at the 1852 Syracuse Convention (Sept. 8-10, 1852). in CONCISE HiSTORY, supra note 36, at $121,121$.

57. See KRADITOR, supra note 26, at 131-38. 
Elizabeth Cady Stanton, explicitly argued that there should be educational requirements for the franchise. ${ }^{58}$ These arguments depended, to some extent, on racist and anti-immigrant views, but they also depended on a belief in the importance of education and character. "We have long known that the safety of a country rests upon the intelligence as much as upon the character of its citizens," explained one suffragist. ${ }^{59}$ And Stanton. quoting unspecified "forefathers," justified her position by proclaiming that " $[\mathrm{t} \mid \mathrm{he}$ stability of a republic depends on the virtue and intelligence of the people." ${ }^{60}$ This is, of course, a classically republican formulation.

The influence of republican ideals did not end with the suffragists: Republican themes have recently been revived by a variety of scholars, ${ }^{61}$ and while the emphasis of these scholars may be different from that of earlier republicans, the two visions have much in common. In the neorepublican vision, as in that of classical republicanism, citizens work together to promote the common good, ${ }^{62}$ which they come to know through active deliberation. Participation in deliberation is itself a good, regardless of the outcome. ${ }^{63} \mathrm{~A}$ variety of viewpoints must be represented in the deliberation; "[d]iscussion and deliberation depend for their legitimacy and efficacy on the existence of conflicting views." ${ }^{6+1}$ In the neo-republican vision, individual rights are crucial, but not as an end in themselves; rather, individual rights are crucial because they are a prerequisite to meaningful deliberation and political participation. ${ }^{65}$ And, finally, for deliberation to be truly effective, all the participants must be equal. Otherwise, deliberation

58. See id. at 133-36; see also, e.g., Frances E.W. Harper, Woman's Political Future, Address to the World's Congress of Representative Women (May 13, 1893), in PUBLIC WOMEN. supra note 38 , at 262,263 ("I do not believe in unrestricted and universal suffrage for either men or women. I believe in moral and educational tests.").

59. Elizabeth Burrill Curtis, The Present Crisis, WOMAN's J., Oct. 2, 1897, reprinted in PUBLIC WOMEN, supra note 38, at 264, 266.

60. Elizabeth Cady Stanton, An Educational Suffrage Qualification Necessary. WOMAN's J., Oct. 2, 1897, reprinted in PUBLIC WOMEN, supra note 38, at 264, 264.

61. See, e.g., Frank I. Michelman, The Supreme Court. 1985 Term-Foreword: Traces of Self-Government, 100 HARV. L. REV. 4 (1986); Suzanna Sherry, Civic Virtue and the Feminine Voice in Constitutional Adjudication, 72 VA. L. REV. 543 (1986); Cass R. Sunstein, Beyond the Republican Revival, 97 YALE L.J. 1539 (1988).

62. See, e.g., Frank Michelman, Law's Republic, 97 YALE L.J. 1493, 1503 (1988): Sunstein, supra note 61 , at 1554 . At least one author has argued that republicanism may provide the basis for a "feminine jurisprudence" because republicanism emphasizes the community-the common good-rather than individual interests. See Sherry, supra note 61.

63. See Michelman, supra note 61 , at 27 (stating that republicanism views political actıvity as a " 'benefit' on the ledger books of life").

64. Sunstein, supra note 61 , at $1575-76$; see also Michelman, supra note 61. at 27 ("Normative reason ... cannot be a solitary activity. Its exercise requires knowledge, including self-knowledge, obtainable only by encounter with different outlooks in public argument."). Michelman develops more fully the argument that republicanism requires pluralısu in Michelman, supra note 62 , at 1526-28.

65. See Sunstein, supra note 61, at 1551 (stating that rights are the "preconditions for or the outcome of an undistorted deliberative process" and that "existence of realms of private autonomy must be justified in public terms"). 
deteriorates into "the imposition of outcomes by self-interested and politically powerful private groups." ${ }^{66}$ True deliberation is not possible in the presence of intimidation, manipulation, or great disparities in power. ${ }^{67}$

Before I continue with my argument, which relies to some extent on the continuing relevance of republican ideals, a few words are in order about what I am and am not claiming, for the "republican revival" has come under heavy fire from those who dispute the revivalists' version of early American history. ${ }^{68}$ Republican revivalists, these critics claim, err when they try to "root republicanism in history by proving that the Founders revered republicanism." ${ }^{69}$ These historians also doubt that it is sound to place republicanism and liberalism in stark opposition, as do some of the revivalists. ${ }^{70} \mathrm{My}$ argument, however, does not rest on the presence of republican ideals in the Constitution or in the Founding generation, and it certainly does not rest on the complete exclusion of liberal ideology. I am more interested in drawing out and expanding the strain of republican ideology that appears, side by side with liberal ideology, in the arguments and rhetoric of the suffragists themselves. Even as vigorous a critic of the legal republican revival as Linda Kerber acknowledges that there has been a "continuous presence throughout the history of American dissent of the rhetoric of a commonwealth of cooperation and civic virtue.... This resilient republican language fused with major liberal elements has continued to be central to American political discourse..."71 It is the vision of the dissenters that interests me. Therefore, as I use the suffragists' republican arguments to suggest a reading of the Nineteenth Amendment that takes republican concerns into account, I rely on the revivalists' work to the extent that they describe aspects of republican ideology and ways to

66. Id. at 1550.

67. See id.

68. The most extended attack on the republican revival comes in KaluMAN. supra note 32 , especially at pages 167-80. A number of other historical and legal scholars have questioned the historical conclusions drawn by the revivalists. See Stoltzenberg. supra note 32. at 1028 n.9 (listing critics of neo-republicanism). Critics have also attacked substantive aspects of neorepublicanism. So, for example, Kalman wams that neo-republicanism may be problematic because it can fit conservatives' ends so well. providing support for the likes of Leo Strauss and Robert Bork: "[My concern here is] that neo-republicanism could be used to justify non-liberal politics. . . . By this analysis, the republican revival would be fundamentally flawed because it is the wrong tool to fix what is broken." Laura Kalman. Border Patrol: Reflections on the Tum to History in Legal Scholarship, 66 FORDHAM L. REV. 87. 108-09 (1997); see also KALMAN, stupra note 32 , at 209-10 \& n.49 (citing substantive and nomative arguments against republicanism). (Of course, a similar objection could be raised about, say, logic.) Stolzenberg's article, supra note 32 , provides a strong argument in suppor of neo-republicanism and against both types of criticism.

69. Kalman, supra note 68 , at 96 .

70. See, e.g., Kalman, supra note 32, at 174 (citing Wood and Pocock to draw into question the "binary reading" of the debate between liberalism and republicanism).

71. Kerber, supra note 31 , at 1672 
achieve republican goals, without necessarily relying on the revivalists' historical claims.

Given the suffragists' republican rhetoric, then, and the persistence of republican thought, one way to understand the meaning of the Nineteenth Amendment is to read it through a republican lens. In particular, a republican understanding of full citizenship helps explain why violence against women interferes with women's ability to be political citizens. It is to this question that I turn in the next Part.

\section{VIOLENCE AGAINST WOMEN INTERFERES WITH POLITICAL CITIZENSHIP}

Violence against women is a political issue because it interferes with women's ability to be political citizens. Political citizenship in a republic requires equal participation in deliberation by people who are able to be free of the exercise of arbitrary power and to engage in self-determination. A culture of violence against women allows men to dominate women and forces women to reshape their actions, desires, and beliefs, thereby interfering with their self-determination and, in this republican country, with their full political participation.

Republicanism, unlike liberalism, does not conceive of liberty as the mere absence of state interference. Rather, both historical and neorepublicanism emphasize the importance of positive liberty. ${ }^{72}$ Republicanism holds that there can be no liberty unless a person is free from the exercise of arbitrary power, whatever its source. This arbitrary power may take the form of physical restraint or threat of punishment, or it may also take the form of manipulation, that is, "the deceptive or nonrational shaping of people's beliefs or desires, or the rigging of the consequences of people's actions." " 73 Without freedom from such domination, a person is unable to be a full citizen. The suffragists knew this well. For example, both Elizabeth Cady Stanton and Lucy Stone believed that a wife's right to her own person - in particular, her right to be free from forced sexual intercourse-was the "necessary foundation for equal citizenship, without which all other legal reform would prove near worthless." 74

In a republican government, therefore, some apparently private interests become matters of political concern. For example, republican self-

72. See PHILIP PETTIT, REPUBLICANISM: A THEORY OF FREEDOM AND GOVERNMENT 17-50 (1997) (arguing that historically, republicanism conceived of liberty as positive freedom from arbitrary power).

73. Id. at 53 .

74. Jill Elaine Hasday, Contest and Consent: A Legal History of Marital Rape, 88 CAL. L. REV. (forthcoming Oct. 2000) (manuscript at 54). 
government would not be possible without secure property interests: Without an "unquestionably secure base of material support," a participant in public affairs would be dependent on someone else for his livelihood and thus would be motivated to act not by the common good, but rather by the interests of his patron or "his own particular, immediate, and possibly delusive material interest." 75 Property is necessary for the personal independence that is required to be a proper republican citizen.

A culture of violence against women is also a matter of political importance. The fact of pervasive violence against women, like a lack of property, may lead a person to make decisions based on something other than a clear-minded evaluation of the best interests of the community. Indeed, the relationship of men to women is paradigmatic of the kind of dominance that republicanism seeks to eliminate. ${ }^{76}$ It does not matter that not every woman is a victim of violence, nor every man a perpetrator. Domination occurs because men have the capacity to interfere arbitrarily with women's acts, and everybody knows this, even if the interference never actually takes place. ${ }^{77}$ Women, because they are women, live with a constant fear of violence, ${ }^{78}$ and they adjust their lives accordingly. This is true at a seemingly trivial level: More women than men carry their keys in their hands when going to their cars, for example, ${ }^{79}$ and many women try not to dress in a provocative manner ${ }^{80}$ or leave the house after dark ${ }^{81}$

The constant threat of danger works more profound changes as well. As Robin West explains, because "[a] fully justified fear of acquisitive and violent male sexuality... permeates many women's-perhaps all women's-sexual and emotional self-definition," women "re-constitut[e] themselves in a way that controls the danger and suppresses the fear." 82 Men too face threats of violence, of course, but those threats are more sporadic than the threats that women face, and men respond not by redefining themselves, but rather by acting: "One responds to sporadic fear

75. Frank I. Michelman, Possession vs. Distribution in the Constitutional Idea of Property, 72 IOWA L. REV. 1319, 1329 (1987).

76. See, e.g., PETTT, supra note 72 , at $57,85,138-40$.

77. See id. at 63-64.

78. See KENNETH F. FERRARO, FEAR OF CRIME: INTER PRETING VICTIMIZATION RISK 85-100 (1995) (explaining that women are more afraid of crime than are men because any victimization of women involves the possibility of sexual assault).

79. See Margaret T. GoRdon \& Stephante RIGER, THE Femiale FEar 18 (1989) (stating that $82 \%$ of women and only $44 \%$ of men always carry their keys in their hands when going to their cars; $20 \%$ of men never do, as opposed to only $4 \%$ of women).

80 . See id. at 17 (stating that $58 \%$ of women and only $10 \%$ of men always try not to dress in a provocative manner, $63 \%$ of men never try not to dress in a provocative manner, as compared with only $18 \%$ of women).

81. See id. at 16 (stating that $72 \%$ of men never restrict themselves to going out only in the daytime and that only $25 \%$ of women never so restrict themselves: $26 \%$ of women always restrict themselves to going out in the daytime, as opposed to only $9 \%$ of men).

82. Robin L. West, The Difference in Women's Hedonic Lives: A Phenomenological Crisique of Feminist Legal Theory, 3 WIS. WOMEN's L.J. 81.94 (1987). 
and the threat of sporadic violence by changing one's behavior." ${ }^{83}$ For example, a man can change neighborhoods, leave a bar-room brawl, or come home from war. ${ }^{84}$ In contrast, women, because they are women, experience pervasive fear and pervasive threats and must actually redefine themselves:

Women cannot eliminate the danger our sexuality poses by moving to a safer neighborhood, any more than blacks can respond to the danger their color poses by moving to a safer race.... We respond to the pervasive threat of violent and acquisitive male sexuality instead by changing ourselves, rather than responding to the conditions which cause it. ${ }^{85}$

In a republican society, such distorted self-determination becomes a political matter, for manipulation and domination must be eliminated to achieve the equality and self-determination necessary for every participant in the deliberation that makes a true republic. Violence against women because they are women thus interferes with women's ability to be full, political citizens.

\section{THE VIOLENCE AGAINST WOMEN ACT AS APPROPRIATE CONGRESSIONAL ACTION UNDER THE NINETEENTH AMENDMENT}

There are two possible ways in which society can respond to a person who lacks something required for effective participation in a republic. The first response, traditionally associated with republicanism, is to exclude that person from the franchise on the grounds that she will not be able to participate effectively. The second is to change the circumstances that make that person unable to participate effectively. For example, a society might choose to exclude from political citizenship a person who does not have enough property to be an effective, independent political citizen; that is, a society might choose to have property requirements for the franchise. ${ }^{86}$ But most states eliminated statutory property requirements in the first half of the nineteenth century, and today it seems clear that the Constitution does not

83. Id.

84. Some men, of course, do not have the option of leaving a dangerous environment. For example, a man might not have the resources to move to a safer neighborhood and might feel that there is no chance he will ever be able to change his situation. It is entirely possible that he too will reconstitute himself in the face of a constant threat of violence; he too will be in circumstances that impair his self-definition. Saying that women qua women experience a constant threat of violence, and that men qua men do not, should not obscure that other factors can make it difficult for men to engage in self-definition.

85. West, supra note 82 , at 94 .

86. See Michelman, supra note 75 , at 1330. 
permit exclusion from the franchise due to lack of property. ${ }^{87}$ (For example, the Constitution now explicitly forbids charging people to vote in federal elections. ${ }^{88}$ This leaves the second approach, which is to make sure that the person acquires enough property to participate competently. ${ }^{89}$ And, in fact, legislatures engage in all sorts of redistributive schemes, from wage and hour laws, to housing codes ${ }^{90}$ to welfare programs. ${ }^{91}$

Similarly, the Nineteenth Amendment provides that a qualified voter may not be denied the right to vote, to be a political participant, because of her gender. If something interferes with a woman's full political participation because she is a woman, the first option-exclusion-is not permissible. Instead, the Constitution mandates that, if the state is in fact complicit in the interference, whatever interferes with women's political rights may be remedied. Violence against women interferes with women's full political participation, ${ }^{92}$ some remedy is called for, and, as I demonstrate below, Congress may be one source of that remedy.

There are two basic requirements for congressional action under the Enforcement Clause of the Nineteenth Amendment, both of which are met by the Violence Against Women Act. First, legislation under the Nineteenth Amendment must be remedial, as defined by the Supreme Court. Second, such legislation may address only those constitutional violations in which the state plays a part. There is no Supreme Court case law that deals directly with the issue of Congress's power under the Nineteenth Amendment; however, the Enforcement Clause of the Nineteenth Amendment is nearly identical to those of several other amendments, including the Fourteenth and Fifteenth Amendments. ${ }^{93}$ In the discussion that follows I use the Supreme Court's well-developed body of case law regarding the limitations and possibilities of congressional power under

87. See id.

88. See U.S. CONST. amend. XXIV (abolishing "any poll tax or other tax" as a requirement for voting in a federal election).

89. See Michelman, supra note 75, at 1330.

90. See id. at 1338 .

91. See, e.g., Goldberg v. Kelly, 397 U.S. 254, 262 \& n.8, 265 (1970) (stating that welfare rights are a statutory entitlement--"more like "property' than a 'gratuity"'- and that " [w]elfare, by meeting the basic demands of subsistence, can help bring within the reach of the poor the same opportunities that are available to others to participate meaningfully in the life of the community").

92. See supra Part III.

93. Compare U.S. CONST. amend. XIX ("Congress shall have power to enforce this article by appropriate legislation."), with id. amend. XIV, §5 ("The Congress shall have power to enforce, by appropriate legislation, the provisions of this article."), and id. amend. XV. $\$ 2$ ("The Congress shall have power to enforce this article by appropriate legislation."). The similarity between some of these clauses has been noted. See, e.g., Lopez v. Monterey County, $119 \mathrm{~S}$. Ct. 693, 709 n.6 (1999) (Thomas, J., dissenting) (stating that the Court has “always treated the nature of the enforcement powers conferred by the Fourteenth and Fiftecnth Amendments as coextensive"). 
these other amendments to shed light on Congress's Nineteenth Amendment powers.

\section{A. The Remedial Requirement}

This Section briefly traces the history of congressional power under the Fourteenth and Fifteenth Amendments, and then focuses on the recent and important development in the Court's Fourteenth Amendment jurisprudence announced in City of Boerne v. Flores.$^{94}$ Acknowledging the analogy between Congress's Fourteenth and Nineteenth Amendment powers, I then show that, even given the Court's limitation of congressional power in Boerne, VAWA is an appropriately remedial use of Congress's Nineteenth Amendment powers.

\section{Legislation Under the Nineteenth Amendment Must Be Remedial}

The Supreme Court has, until recently, given Congress extremely broad power under the enforcement clauses of the Fourteenth and Fifteenth Amendments. The Court has held that the appropriate test to apply when judging the powers of Congress under the Fourteenth and Fifteenth Amendments is the test laid down in McCulloch v. Maryland: ${ }^{95}$ "Let the end be legitimate, let it be within the scope of the constitution, and all means which are appropriate, which are plainly adapted to that end, which are not prohibited, but consist with the letter and spirit of the constitution, are constitutional." 96

The Court has also ruled that, under the power conferred by the Civil War amendments, Congress may prohibit behavior that is not in itself unconstitutional. For example, in Katzenbach v. Morgan, the Court upheld, as a valid use of power conferred by the Enforcement Clause of the Fourteenth Amendment, a provision of the Voting Rights Act of 1965 that stated that anyone who had completed the sixth grade at an American or Puerto Rican school at which the primary language of instruction was not English could not be denied the right to vote because of his inability to

94. 521 U.S. 507 (1997).

95. 17 U.S. (4 Wheat.) 316 (1819).

96. Id. at 421, quoted in South Carolina v. Katzenbach, 383 U.S. 301, 326 (1966) (applying the $\mathrm{McCulloch}$ test to the Fifteenth Amendment); see also Katzenbach v. Morgan. 384 U.S. 641 . 651 (1966) (applying the test to the Fourteenth Amendment); Ex parte Virginia, 100 U.S. 339. $345-46$ (1880) ("Whatever legislation is appropriate, that is, adapted to carry out the objects the [Thirteenth and Fourteenth] amendments have in view, whatever tends to enforce submission to the prohibitions they contain, and to secure to all persons the enjoyment of perfect equality of civil rights and the equal protection of the laws against State denial or invasion, if not prohibited. is brought within the domain of congressional power."); $c f$. James Everard's Breweries v. Day, 265 U.S. 545, 558-59 (1924) (applying the McCulloch test to the Eighteenth Amendment). 
read, write, or understand English. ${ }^{97}$ The Court upheld this provision notwithstanding the Court's decision in Lassiter v. Northampton County Board of Elections ${ }^{98}$ that literacy requirements for voting were indeed constitutional, barred by neither the Fourteenth nor Fifteenth Amendment. The Court thus held that Congress may prohibit actions even if those actions are themselves constitutional. This was not a controversial proposition then, and remains uncontroversial today. ${ }^{9}$

More controversial was the Court's vision in Morgan of the extent of Congress's enforcement power. The Court provided two alternative grounds for its holding that the provision in question fell within Congress's power to enact under the Fourteenth Amendment. First, the Court suggested that the provision might have been meant by Congress to enhance Puerto Ricans' political power and thus help gain "nondiscriminatory treatment in public services for the entire Puerto Rican community." ${ }^{100}$ Second, the Court stated that Congress might have decided that the literacy provision barred by the Act "constituted an invidious discrimination in violation of the Equal Protection Clause." ${ }^{101}$ The Court in Morgan seemed to accept such a congressional conclusion even though the Cour itself had already held, in Lassiter, that literacy tests did not violate the Equal Protection Clause. The Court's second holding has sometimes been characterized as granting Congress the power "not just to punish violations, but also to define and expand the scope of the Equal Protection Clause." 102

The Court has not adhered to this broad view of Congress's power. Congress's power to define the scope of the Fourteenth Amendment was questioned in Oregon v. Mitchell ${ }^{103}$ and in Justice Rehnquist's dissent in City of Rome ${ }^{104}$ and specifically rejected in Boerne, ${ }^{105}$ which restricted Congress's creative powers under the Civil War amendments' enforcement

97. Pub. L. No. $89-110$, tit. I, $\$ 4,79$ Stat. 438 (1965) (current version at 42 U.S.C. $\S 1973 \mathrm{~b}(e)(2)(1994))$, cited in Morgan, 384 U.S. at 643 n.1.

98. 360 U.S. 45 (1959).

99. See Boerne, 521 U.S. at 518 ("Legislation which deters or remedies constitutional violations can fall within the sweep of Congress' enforcement power even if in the process it prohibits conduct which is not itself unconstitutional ...."); City of Rome v. United States, 446 U.S. 156, 210 (1980) (Rehnquist, J., dissenting) ("It has never been seriously maintained ... that Congress can do no more than the judiciary to enforce the Amendments' commands." ); James Everard's Breweries, 265 U.S. at 558-59 (holding that under the Enforcement Clause of the Eighteenth Amendment, Congress could prohibit the prescription of intoxicating liquor for medicinal purposes, even though the amendment only prohibited the sale of intoxicating liquor for beverage purposes).

100. Morgan, 384 U.S. at 652.

101. Id. at 656 .

102. Adarand Constructors v. Pena, 515 U.S. 200, 255 n.ll (1995) (Stevens, J., dissenting) (emphasis added); see also, e.g., Fullilove v. Klutznick, 448 U.S. 448. 501 (1980) (Powell. J.. concurring) (citing Morgan and South Carolina for the proposition that Congress has power to "find ... constitutional violations" under both the Fourteenth and Fifteenth Amendments).

103. 400 U.S. 112, 209 (1970) (opinion of Harlan. J.); id. at 296 (opinion of Stewart. J.).

104. 446 U.S. at 220 n. 8 .

105. 521 U.S. at $527-28$. 
clauses. Boerne held unconstitutional the Religious Freedom Restoration Act of 1993 (RFRA), ${ }^{106}$ in which Congress, acting under its Fourteenth Amendment Enforcement Clause powers, mandated the highest level of judicial scrutiny for any law, even one of general applicability, if that law substantially burdened a person's exercise of religion. RFRA was Congress's attempt to overrule the Court's prior decision, in Employment Division v. Smith ${ }^{107}$ that a test balancing the burdening of an individual's religious practice against the government's interest in that burden was not appropriate for neutral, generally applicable laws. ${ }^{108}$

Boerne set out three guidelines for congressional action under the Civil War amendments. First, according to the Court, Congress's power under the Civil War amendments is "remedial" rather than "substantive." 109 Second, if Congress is to exercise its powers under the Civil War amendments, there must first exist a constitutional wrong under the amendment in question to be remedied or prevented. ${ }^{110}$ Third, Boerne required Congress to devise a remedy for the wrong that was "appropriate": There had to be "congruence and proportionality between the injury to be prevented or remedied and the means adopted to that end." 111

Phrased another way, the Court ruled that Congress may enforce, but not define, rights, ${ }^{112}$ and identified the forbidden act of definition in two separate ways. One way the Court knew that Congress was engaged in definition, not enforcement, was that Congress's action contradicted a previous action of the Court. Such a contradiction in itself indicated that definition was occurring. ${ }^{113}$ Thus the Court in Boerne could accommodate the holdings of most of the relevant precedent, but had to renounce the

106. 42 U.S.C. $\$ \S 2000 \mathrm{bb}$ to $2000 \mathrm{bb}-4$ (1994).

107. 494 U.S. $872(1990)$.

108. See 42 U.S.C. $\$ 2000 \mathrm{bb}(\mathrm{a})$, (b) (stating that Congress's purpose was to reinstate the test rejected by Smith).

109. See Boerne, 521 U.S. at 520-28 (reviewing the legislative history of the Fourteenth Amendment and the Court's earlier decisions regarding the remedial nature of Congress's power). But see Steven A. Engel, Note, The McCulloch Theory of the Fourteenth Amendment: City of Boerne v. Flores and the Original Understanding of Section 5. 109 YALE L.J. 115, 117 (1999) (arguing that it was 'the Framers' conviction that it would be Congress, and not the courts. that would be the first reader, and primary enforcer, of the Fourteenth Amendment").

110. See Florida Prepaid Postsecondary Educ. Expense Bd. v. College Sav. Bank, 119 S. Ct. 2199,2207 (1999) (stating that Boerne holds that "for Congress to invoke $\$ 5$ lof the Fourteenth Amendment], it must identify conduct transgressing the Fourteenth Amendment's substantive provisions").

111. Boerne, 521 U.S. at 520.

112. See id. at 519-20.

113. See id. at 519 (explaining that Congress may not "alter[] the meaning" of a constitutional provision or "chang[e] what [a constitutional] right is"); see also id. at 536 ("When the political branches of the Government act against the background of a judicial interpretation of the Constitution already issued, it must be understood that in later cases and controversies the Court will treat its precedents with the respect due them under settled principles ... and contrary expectations must be disappointed."). 
"alternative" holding in Morgan that Congress could have determined, notwithstanding Lassiter, that literacy tests constituted an invidious discrimination under the Fourteenth Amendment. ${ }^{14}$ One reason, then, that RFRA failed is that it contradicted the Court's earlier holding in Smith.

RFRA also failed for a reason related to, but distinct from, the fact that it defied an earlier decision of the Court: RFRA was definitional and not remedial because the Court said that there was not a "proportionality or congruence" between the injury to be prevented or remedied and the means that Congress adopted to prevent or remedy that injury. ${ }^{115}$ The important change here was not that Congress's means had to meet certain standards; Congress's actions have always had to be appropriate. The important change was that the Court, not Congress, evaluated the appropriateness of congressional action. Of course, even before Boerne the Court could-and did-review Congress's actions under the Fourteenth and Fifteenth Amendments to determine whether those actions were constitutional. ${ }^{116} \mathrm{But}$ the test that the Court applied in the past to Congress's determinations of both the wrong to be remedied and the appropriateness of that remedy was the lowest level of scrutiny possible - a version of the "rational basis" test. ${ }^{117}$ While this deference to Congress was paid lip service in Boerne, ${ }^{118}$ the Court's real point was that "Congress' discretion is not unlimited." 119 The text and the outcome of Boerne clearly show that it is now the province of the Court to weigh conflicting considerations and determine the appropriateness of legislation.

However, the Court did not state clearly in Boerne what factors it might consider in future cases to determine the appropriateness of congressional action. For example, while the lack of legislative history detailing a real problem was relevant to the Court's determination in Boerne, ${ }^{120}$ that lack was not dispositive. ${ }^{121}$ Similarly, the Court seemed to base its decision on

114. See supra text accompanying notes 101-102.

115. Boerne, 521 U.S. at 533.

116. See, e.g., City of Rome v. United States, 446 U.S. 156 (1980): Morgan v. Katzenbach. 384 U.S. 641 (1966); South Carolina v. Katzenbach. 383 U.S. 301 (1966).

117. See, e.g., Rome, 446 U.S. at 177 (upholding congressional action because "Congress could rationally" have reached the conclusion that "it was proper" to enact the provisions in question (emphasis added)); Morgan, 384 U.S. at 653 ("It is enough that we be able to perceive a basis upon which the Congress might solve the conflict as it did."); South Carolina v. Katzenbach. 383 U.S. at 324 ("Congress may use any rational means to effectuate the constitutional prohibition of racial discrimination in voting." (emphasis added)).

118. See, e.g., Boerme, 521 U.S. at 536 (citing Morgan for the propositions that Congress may determine what legislation is needed to enforce the Fourteenth Amendment and that Congress's "conclusions are entitled to much deference").

119. Id.

120. See id. at 530-31 (discussing the lack of legislative history supportive of RFRA).

121. See id. at 531-32 ("This lack of suppon in the legislative record ... is not RFRA's most serious shortcoming. Judicial deference, in most cases, is based not on the state of the legislative record Congress compiles but 'on due regard for the decision of the body constitutionally appointed to decide.' As a general matter, it is for Congress to determine the method by which it 
RFRA's lack of "termination dates, geographic restrictions, [and] egregious predicates," ${ }^{122}$ but then stated that none of these is required by Section 5 of the Fourteenth Amendment. ${ }^{123}$

In short, the Court's decision in Boerne held that only remedial legislation is appropriate under the Fourteenth Amendment. Boerne also provided a definition of remedial: To be remedial, legislation must not directly contradict previous Supreme Court precedent and must be proportional and congruent to the evil to be remedied. Although the Court made it clear that it may in the future submit congressional actions to fairly strict scrutiny in determining whether legislation is proportional and congruent, it did not provide clear guidelines for Congress to follow in order to ensure the Court's approval of legislation.

\section{VAWA Is Appropriately Remedial}

Under the Supreme Court's current definition of "remedial," the Violence Against Women Act is an appropriately remedial use of congressional power under the Nineteenth Amendment. The constitutional violation remedied is the existence of a culture of violence against women, which prevents women from becoming fully participating political citizens. ${ }^{124}$ There is extensive legislative history documenting the problem of violence against women. The Act is also narrowly tailored: Although all women are harmed by a culture of violence against women, the Act permits only those women who are physically harmed by violence because of their gender to bring a cause of action. And the Act does not contradict any previous action of the Court.

Congress made extensive legislative findings that confirm that violence against women is a serious problem in this country. Congressional reports are full of statistics demonstrating the pervasiveness of violence against

will reach a decision." (citation omitted)). A more recent decision suggests that the Court will place great weight on the lack of a legislative recond identifying a history of constitutional violations. In Florida Prepaid Postsecondary Education Expense Board v. College Savings Bank, 119 S. Ct. 2199, 2207-10 (1999), the Court spent a good deal of time examining the legislative history of the challenged act. The Court did state that "the lack of [evidence of constitutional violations] in the legislative record is not determinative," id. at 2210 , but in the very next paragraph found that "[b]ecause of this lack [of evidence], the provisions of [the act in question] are "so out of proportion to a supposed remedial or preventive object that [they] cannot be understood as responsive to, or designed to prevent, unconstitutional behavior," id. (last alteration in original) (quoting Boerne, 521 U.S. at 532), and that the act in question was therefore not a proper use of Congress's Fourteenth Amendment powers.

122. Boerne, 521 U.S. at 533.

123. See id.

124. See supra Part III. 
women, ${ }^{125}$ and Congress held many hearings in which individual women testified about their own or others' personal experiences with violence against women. ${ }^{126}$ Such findings differ drastically from the legislative history of RFRA, which as the Court stated in finding RFRA unconstitutional, "lack[ed] examples of modern instances of generally applicable laws passed because of religious bigotry" and "mention[ed] no episodes occurring in the past 40 years." ${ }^{127}$

In addition, the civil rights provision of the Act is narrowly tailored: It is congruent and proportional to the serious constitutional violation it seeks to remedy. Although all women, not just those who are actually victims of the violence, suffer from a culture of violence against women, the Act provides a cause of action only to women who have actually suffered physical violence. Moreover, violence is actionable under the Act only if it is violence "motivated by gender," ${ }^{28}$ and the violence must be so severe that it would constitute a felony if criminally prosecuted. ${ }^{129}$ The Act might be considered too broad because, notwithstanding the fact that there is no evidence of violence against men because of their gender, the Act is not limited to violence against women by men, but instead applies to any act of violence, by man or woman, against anyone, if committed on account of the victim's gender ${ }^{130}$ But this argument proves too much. If it is correct, the Voting Rights Act of 1965 is likewise unconstitutional, since it prohibits interference with voting "on account of race or color" ${ }^{131}$ and there is no history of states' restricting white people's right to vote on account of their race. Gender-neutral language simply meets the requirements of the Equal Protection Clause. ${ }^{132}$ In addition, the Act makes no substantive change in

125. See, e.g., H. R. REP. No. 103-395, at 25-27 (1993); S. REP. No. 103-138, at 37-38, 41 42 (1993); S. REP. No. 102-197, at 33-34, 36-39 (1991); S. REP. No. 101-545, at 27-33 (1990); supra notes 3, 5-7 and accompanying text.

126. See S. REP. No. 103-138, at 39 (describing five separate hearings that detailed the problem of violence against women).

127. Boerne, 521 U.S. at 530; see also Florida Prepaid Postsecondary Educ. Expense Bd. v. College Sav. Bank, 119 S. Ct. 2199, 2207-10 (1999).

128. See, e.g., 42 U.S.C. $\$ 13981$ (b) (1994).

129. See id. $\S 13981$ (d)(2)(A) (defining "crime of violence").

130. See, e.g., Brzonkala v. Virginia Polytechnic Inst. \& State Univ., 169 F.3d 820, 887 (4th Cir. 1999) (en banc) (holding that the civil rights provision of VAWA is overbroad because, inter alia, it is "written in gender-neutral terms and would presumably create a cause of action for a male plaintiff, even though there is no evidence, or even any suggestion, that the States have unconstitutionally enforced their laws that disproportionately affect men ${ }^{\text {m) }}$, cerr. granted, 68 U.S.L.W. 3021 (U.S. Sept. 28, 1999) (Nos. 99-5, 99-29).

131. Voting Rights Act of $1965, \S 2,42$ U.S.C. \$1973 (1994).

132. See, e.g., Mississippi Univ. for Women v. Hogan, 458 U.S. 718 (1982); Craig v. Boren, 429 U.S. 190 (1976). An equal protection argument also explains why the Act should cover samesex violence on account of gender. If the Act did not cover same-sex violence, a woman attacked by a man because of gender would be protected, but a man attacked by a man because of gender would not be protected. This discrimination against the male victim would constitute a violation of the Equal Protection Clause. For an elaboration of this sort of argument in the context of 
the law. It does not increase the level of judicial scrutiny for acts that incidentally discriminate on the basis of gender. ${ }^{133}$ Instead, the Act simply provides a different remedy for acts that already would be considered criminal. Therefore, VAWA is in harmony with the Supreme Court's case law regarding congressional action under the enforcement clauses of the Fourteenth and Fifteenth Amendments, and is an appropriately remedial use of Congress's analogous power under the Nineteenth Amendment.

\section{B. The State Action Requirement}

This Section establishes that Congress may act under the Nineteenth Amendment only if the constitutional violations Congress addresses involve state action of some sort. I first show that the plain language of the Nineteenth Amendment and analogous cases decided under the Fourteenth and Fifteenth Amendments demonstrate that state involvement in a constitutional violation is a prerequisite for congressional action under the Nineteenth Amendment, and examine the scope of that state action requirement. I then show that VAWA meets the state action requirement under the Nineteenth Amendment, because the state creates marriage and marriage contributes to a culture of violence against women, which interferes with women's ability to be political citizens.

\section{Legislation Under the Nineteenth Amendment Must Remedy State Action}

On its face, the Nineteenth Amendment prohibits only action by the state: ${ }^{134}$ Private action standing alone cannot be unconstitutional under the

\footnotetext{
sodomy laws, see Andrew Koppelman, Note, The Miscegenation Analogy: Sodomy Law as Sex Discrimination, 98 YALE L.J. 145 (1988).

133. VAWA is thus immune to the sort of argument made by, for example, the dissenting judge in Coolbaugh v. Louisiana, 136 F.3d 430, 439 (5th Cir. 1998) (Smith. J., dissenting). That judge argued that after Boerne, the Americans with Disabilities Act (ADA) cannot be a valid enactment under the Fourteenth Amendment because it increases the "level of judicial scrutiny for states' actions that incidentally burden disabled persons." Id. He pointed out that the Supreme Court has held that disabled people are not a suspect or quasi-suspect class, and that legislation having incidental burdens on the disabled was permissible if it was rationally related to a legitimate government purpose. See $i d$. at 440 (citing City of Cleburne v. Cleburne Living Cir.. 473 U.S. 432 (1985)). If this argument is correct, the ADA goes against this previous ruling of the Supreme Court when it requires the state to demonstrate that it cannot reasonably accommodate the disabled before the courts will validate the state's chosen policy. See id. at 441 .

134. See U.S. CONST. amend. XIX ("The right of citizens of the United States to vote shall not be denied or abridged by the United States or by any State on account of sex." (emphasis added)); $c f$. U.S. CONST. amend. XV ("The right of citizens of the United States to vote shall not be denied or abridged by the United States or by any State on account of race, color, or previous condition of servitude." (emphasis added)).
} 
Nineteenth Amendment. ${ }^{135}$ More importantly for the purposes of this Note, although "[1]egislation which deters or remedies constitutional violations can fall within the sweep of Congress' enforcement power even if in the process it prohibits conduct which is not itself unconstitutional," ${ }^{136}$ the Court has ruled that Congress may not act to remedy purely private action under its Fifteenth Amendment powers. For example, in James $v$. Bowman, ${ }^{137}$ the Court found that Congress had exceeded its powers when it passed a statute that made it a crime for any person to interfere with the right of suffrage granted by the Fifteenth Amendment: "[T]he section purports to be an exercise of the power granted to Congress by the Fifteenth Amendment.... But that amendment relates solely to action 'by the United States or by any state,' and does not contemplate wrongful individual acts." 138 The Court concluded that "a statute which purports to punish purely individual action cannot be sustained as an appropriate exercise of the power conferred by the Fifteenth Amendment upon Congress ...." ${ }^{139}$ The Court has characterized Congress's power to enforce the Fourteenth and Fifteenth Amendments as "parallel," and has cited Bowman to support its statement that congressional power under the Fourteenth Amendment extends only to "the "power to provide modes of redress' against offensive state action." ${ }^{140}$ And in Terry $v$. Adams, ${ }^{1+1}$ Justice Frankfurter stated that "[t]he [Fifteenth Amendment] command against ... denial or abridgement [of the right to vote based on race or color] is directed to the United States and to the individual States. Therefore, violation of this Amendment and the enactments passed in enforcement of it must involve the United States or a State." ${ }^{1 / 2}$

135. Fifteenth Amendment cases provide suppon for this conclusion. For example. in Grovey v. Townsend, 295 U.S. 45 (1935), the Court found that primary elections were not part of state action, and thus the denial of the right to vote in a primary election did not violate the Fifteenth Amendment. Grovey was overnuled by Smith v. Allwright, 321 U.S. 649 (1944), but the way in which it was overruled only emphasizes the state action requirement: The Cour found that actions taken at a primary were in fact state actions. and thus came within the purview of the Fifteenth Amendment. As the Court put it, the Fifteenth Amendment forbids "the abridgement by a State of a citizen's right to vote." $I d$. at 666 . A primary was "state action within the meaning of the Fifteenth Amendment." Id. at 664. In other words, Allwright only reiterated the necessity of state action for court action under the Fifteenth Amendment. See also Terry v. Adams, 345 U.S. 461. 485 (1953) (Minton, J., dissenting) (stating that " this Court has power to redress a wrong under [the Fifteenth] Amendment only if the wrong is done by the State").

136. City of Boerne v. Flores, 521 U.S. 507, 518 (1997).

137. 190 U.S. 127 (1903).

138. Id. at 136.

139. Id. at 139.

140. Boerne, 521 U.S. at 518,525 (emphasis added) (citation omitted).

141. 345 U.S. 461 (1953).

142. Id. at 473 (opinion of Frankfurter. J.) (emphasis added). Michael Les Benedict claims that in the 1870s and 1880s, the Waite Supreme Cour "sustained Congress's power to protect voting rights against racially motivated private assaults." Michael Les Benedict. Preserving Federalism: Reconstruction and the Waite Court, 1978 SUP. CT. REv. 39, 73. To support this claim, Benedict points to the cases of United States v. Harris. 106 U.S. 629 (1883): United Srates 
Griffin v. Breckenridge $e^{143}$ and United States v. Guest ${ }^{144}$ have been characterized as permitting legislation under Section 5 of the Fourteenth Amendment to reach private action, ${ }^{145}$ but in fact in both cases the Court explicitly found that the right being protected did not stem from the Fourteenth Amendment ${ }^{146}$ and deferred the question of whether the statutes in question could ever reach private action that interfered with rights that stemmed only from the Fourteenth Amendment. ${ }^{147}$ When the Court did reach that question for the statute involved in Griffin, it made it clear that the statute did not protect rights with a state action requirement from infringement by private parties. ${ }^{148}$ Therefore, legislation under the

v. Cruikshank, 92 U.S. 542 (1876); and United States v. Butler, 25 F. Cas. 213 (C.C.D.S.C. 1877) (No. 14,700). The key case for this proposition is Butler, which is not in fact a Supreme Court case, but rather a case over which Chief Justice Waite presided while riding circuit. In that case, which involved violence against black men who were trying to vote, Waite did seem to assume that there was no state action requirement under the Fifteenth Amendment. See Butler, 25 F. Cas. at 224. However, when faced with essentially the identical situation as arose in Butler, the Supreme Court declined to reach the same conclusion, choosing to locate the right to vote in a congressional election not in the Fifteenth Amendment, but in a part of the Constitution that had no state action requirement. See Ex parte Yarbrough, 110 U.S. 651, 663-64 (1884). As for Cruikshank and Harris, both simply limit the application of statutes passed under Congress's Fifteenth Amendment powers on grounds other than a lack of state action. See Harris, 106 U.S. at 637; Cruikshank, 92 U.S. at 555. In both cases the Court also found, on the basis of Fourteenth Amendment's state action requirement, that the sections in question could not apply to privute action. See Harris, 106 U.S. at 637-39; Cruikshank, 92 U.S. at 554-55. To conclude that there is no state action requirement for the Fifteenth Amendment simply because the Court chose different grounds on which to invalidate the statutes in question seems an unwarranted leap-an extraordinarily strong version of expressio unius est exclusio alterius.

143. 403 U.S. 88 (1971).

144. 383 U.S. 745 (1966).

145. See Violence Against Women: Victims of the System: Hearing on S. 15 Before the Senate Comm. on the Judiciary, 102d Cong. 98 (1992) [hereinafter Victims of the System] (statement of Burt Neuborne, Professor of Law, New York University School of Law).

146. See Griffin, 403 U.S. at 106; Guest, 383 U.S. at 759 n.17.

147. See Griffin, 403 U.S. at 107; Guest, 383 U.S. at 754-55.

148. See United Bhd. of Carpenters, Local 610 v. Scott, 463 U.S. 825, 833-34 (1983); see also Bray v. Alexandria Women's Health Clinic, 506 U.S. 263, 274-78 (1993) (reiterating the requirement that for a conspiracy to be actionable under $\S 1985(3)$, it must involve an intent to "deprive persons of a right guaranteed against private impairment"). Neuborne tried to distinguish VAWA from $\S 1985(3)$ on the grounds that

$\S 1985(3)$... was intended to operate solely as a conduit for substantive rights created elsewhere, [but the civil rights provision of VAWA] is carefully designed to itself create a federal statutory right to be free from gender-motivated assault. As the Court noted in [United Brotherhood], if $\S 1985(3)$ had itself created the rights in question, either pursuant to the commerce clause or Section 5 of the [Fourteenth] Amendment. Congress would have been clearly empowered to act against private violence.

Victims of the System, supra note 145, at 99 (emphasis added) (citation omitted). Neuborne's claim is, however, based a mischaracterization of United Brotherhood, which actually said only that legislation under the Commerce Clause could create the right to be free from purely private action. See United Bhd., 463 U.S. at 833. The case nowhere states that legislation under the Fourteenth Amendment may proscribe purely private action. (Congress can, however, proscribe private action that combines with state action to create a constitutional violation. See infra Subsection IV.B.2.a.) 
Fourteenth-and by implication the Nineteenth-Amendment may not reach purely private action.

\section{VAWA Remedies State Action}

\section{a. The Nature of the State Action Requirement}

Although legislation passed under the Nineteenth Amendment must remedy state action, the state action involved need be neither exclusive, ${ }^{149}$ nor direct, ${ }^{150}$ nor obvious. ${ }^{151}$ As the Court has stated in the context of the Fourteenth Amendment, "In a variety of situations the Court has found state action of a nature sufficient to create rights under the [Fourteenth Amendment] even though the participation of the State was peripheral, or its action was only one of several co-operative forces leading to the constitutional violation." 152

In one case, the Court found that a restaurant owner who leased space in a public building could be enjoined from refusing to serve the plaintiff because of the plaintiff's race. ${ }^{153}$ The Court found that the state action in that case was public ownership of the building, but the Court did not enjoin the state action directly - that is, the Court did not say that the state had, for example, to sell the building. Instead, the Court found that it was within the power of the judiciary to reach the private component of the action and order the restaurant owner to allow black people into his restaurant.

Similarly, the Court has found that the Fourteenth Amendment means that racially restrictive covenants created by private individuals are unenforceable. ${ }^{154}$ The Court reached this conclusion even though, in the cases before it, no action by state legislatures or city councils was involved, and "the particular patterns of discrimination and the areas in which the restrictions are to operate, are determined, in the first instance, by the terms of agreements among private individuals." ${ }^{155}$ The Court found the requisite state action in the lower court's mere enforcement of the private covenants: " [I]n granting judicial enforcement of the [private] restrictive agreements in

149. Cf. Guest, 383 U.S. at 755 (stating that state action for the purposes of the Fourteenth Amendment need not have been the only factor that contributed to the constitutional violation).

150. Cf. id. (stating that state action for the purposes of the Foureenth Amendment need not be direct).

151. Cf. Burton v. Wilmington Parking Auth., 365 U.S. 715, 722 (1961) (emphasizing the importance of discovering the "true significance" of the "nonobvious involvement of the State" for the purposes of evaluating a possible violation of the Fourteenth Amendment).

152. Guest, 383 U.S. at 755-56.

153. See Burton, 365 U.S. 715.

154. See Shelley v. Kraemer, 334 U.S. 1 (1948); see also Barrows v. Jackson, 346 U.S. 249 (1953) (holding that a state-court award for damages for breach of a racially restrictive covenant constitutes state action for the purposes of the Fourteenth Amendment).

155. Shelley, 334 U.S. at 13. 
these cases, the States have denied petitioners the equal protection of the laws and ... therefore, the action of the state courts cannot stand." 156

The Court also found that the Fourteenth Amendment forbade trespass convictions resulting from an attempt by blacks to be served in a private restaurant that had traditionally been whites-only. ${ }^{157}$ Again, the Court made such a finding notwithstanding the fact that there was no statute or ordinance requiring segregated restaurants. The Court instead focused on public statements made by the city's mayor and superintendent of police opposing sit-ins. ${ }^{158}$ Although neither statement had explicitly commanded that places of business or restaurants be segregated, the Court held that the statements were sufficient state actions to trigger the power of the Fourteenth Amendment and invalidate the trespass convictions. ${ }^{159}$ In short, Fourteenth Amendment jurisprudence suggests that, while legislation enacted under the Nineteenth Amendment is permitted to remedy only constitutional violations in which the state plays a part, such legislation may reach private action that combines with nonexclusive, indirect, nonobvious state action to create those constitutional violations.

\section{b. Marriage as State Action}

VAWA meets the state action requirement for congressional action under the Nineteenth Amendment because the state plays an active role in the creation of a culture of violence against women. Specifically, states create marriage, ${ }^{160}$ which is a cooperative force that leads to such a culture. ${ }^{161}$ Clearly marriage itself is not a sufficient condition for violence against women to occur; a marriage without a violent private actor will not be a violent marriage. Nor is marriage a necessary condition for violence against women. Many individual marriages are positive goods; thus I do not here advocate the abolition of marriage. Nonetheless, historically, law and culture have worked together to create the current idea of marriage-an

156. Id. at 20.

157. See Lombard v. Louisiana, 373 U.S. 267 (1963).

158. See id. at $270-72$.

159. See id. at 273-74.

160. See, e.g., Baehr v. Lewin, 852 P.2d 44, 58 (Haw. 1993) ("Marnage is state-conferred legal partnership status ...."); Nan D. Hunter, Marriage, Law, and Gender: A Feminist Inquiry. 1 LAW \& SEXUALITY 9, 13 (1991) ("Marriage is . . a complete creation of the law, secular or ecclesiastical.... [I]t did not and does not exist without the power of the state (or some comparable social authority) to establish, define, regulate, and restrict it. Beyond such social constructs, individuals may couple, but they do not "marry."'); Richard D. Mohr. The Case for Gay Marriage, 9 NOTRE DAME J.L. ETHICS \& PUB. POL'Y 215, 225 (1995) ("[M)arriage is entirely a creature of the law...."). But see Steven K. Homer, Note, Against Marriage, 29 HARV. C.R.-C.L. L. REV. 505, 514 (1994) (arguing that marriage as a legal entity has a "dual character": that it is "a fundamental relationship that precedes the state" as well as a "stateconferred legal status" (internal quotation marks omitted)).

161. See infra text accompanying notes 178-207. 
idea that incorporates the subordination of women, the idea that women can be dominated, owned, and even brutalized by men. I argue that although laws have changed, these changes serve only to reinforce women's subordination in marriage, and that as states perpetuate the institution of marriage, they perpetuate the old ideas that continue to burden the institution.

Marriage is, without question, a state action. As the Supreme Court has stated, "[W]e are unaware of any jurisdiction where private citizens may covenant for or dissolve marriages without state approval." 162 That approval may be contingent upon, for example, the respective ages ${ }^{163}$ or blood relation ${ }^{164}$ of the prospective bride and groom. The state may recognize only those unions performed by certain people, such as justices of the peace or ministers. ${ }^{165}$ Similarly, there is "state monopolization of the means for legally dissolving [the marriage] relationship." 160 In short, it is the state that decides whether and when a person may enter or leave a marriage. ${ }^{167}$

This state regulation means that, as the Supreme Court wrote in 1888, marriage is "something more than a mere contract." "las Once two people marry, a relation is created that they cannot change by themselves; while other contracts may be modified or dissolved upon the consent of the parties, in marriage the state "steps in and holds the parties to various obligations and liabilities." 169 According to the Court, this state action is appropriate because marriage is "an institution, in the maintenance of which in its purity the public is deeply interested, for it is the foundation of the family and of society, without which there would be neither civilization nor progress." ${ }^{170}$ In many states, this conception of marriage has not changed since 1888. Many courts still hold, as a North Carolina court recently wrote, that

[t]he marriage relation is a peculiar and important one. The courts treat it as a contract only in the sense that contract-consent of the

162. Boddie v. Connecticut, 401 U.S. 371,376 (1971).

163. See, e.g., CONN. GEN. STAT. $\$ 46 \mathrm{~b}-30$ (1999).

164. See, e.g., id. § $46 \mathrm{~b}-10$.

165. See, e.g., id. \$ 46b-22.

166. Boddie, 401 U.S. at 374.

167. See, e.g., Maynard v. Hill, 125 U.S. 190, 205 (1888) ("Marriage, as creating the most important relation in life, as having more to do with the morals and civilization ... than any other institution, has always been subject to the control of the legislature. That body prescribes the age at which parties may contract to marry, the procedure or form essential to constitute marriage ... and the acts which may constitute grounds for its dissolution."). Maynard was cited in Loving v. Virginia, 388 U.S. 1, 7 (1967), for the proposition that "[m]arriage is a social relation subject to the State's police power."

168. Maynard, 125 U.S. at 210-11.

169. Id. at 211 .

170. Id. 
parties-precedes it and is essential to its validity. But, when formed, it is more than a civil contract; it is a relation, an institution, affecting not merely the parties, like business contracts, but offspring particularly, and society generally. ${ }^{171}$

Marriage is also, empirically, a dangerous institution for women. Domestic violence remains a serious problem in this country, ${ }^{172}$ and marriage is a risky undertaking for a woman. This is not because marriage is somehow naturally contentious and potentially dangerous for all involved; rather, marriage is particularly dangerous for women. For example, in 1992, at least $18 \%$ of female victims (roughly 622 out of 3454 female victims) of homicide were murdered by their husbands or exhusbands. ${ }^{173}$ In contrast, only $2.2 \%$ of male murder victims (that is, about 227 out of 10,351) were murdered by their wives or ex-wives. ${ }^{174}$ There were more women beaten by their husbands in 1990 than there were new brides. ${ }^{175}$ Leaving a marriage is also hazardous for women: For violent crimes excluding murder, the victimization rate of women separated (but not divorced) from their husbands was three times higher than that of divorced women and twenty-five times higher than that of married (but not separated) women. ${ }^{176}$

To understand just which "obligations and liabilities" 177 are attached to marriage, and how these obligations and liabilities interact with violence against women, I first examine the status of married women in the early nineteenth century, when the woman's rights movement began. I then look

171. Poston v. Poston, 436 S.E.2d $854,855-56$ (N.C. Ct. App. 1993) (quoting State v. Hairston, 63 N.C. 451, 453 (1869)); see also, e.g., Klein v. Mayo, 367 F. Supp. 583, 585 (D. Mass. 1973) (citing, inter alia, Maynard to support the proposition that "[m]arriage has long been held to be a social relation clearly subject to state regulation"); Carabetta v. Carabetta, 438 A.2d 109, 111 (Conn. 1980) ("Although a marital relationship is in its origins contractual, depending as it does upon the consent of the parties, 'a contract of marriage is sui generis. It is simply introductory to the creation of a status, and what that status is the law determines."' (citation omitted)); Nelson v. Marshall, 869 S.W.2d 132, 134 (Mo. Ct. App. 1993) ("[M]arriage is a contract as well as a status or a legal condition ...." (emphasis added)); Creason v. Myers, 350 N.W.2d 526, 527 (Neb. 1984) ("Marriage results in a status."); Washington Statewide Org. of Stepparents v. Smith, 536 P.2d 1202, 1205 (Wash. 1975) (en banc) (citing various sources. including Maynard, to support the proposition that "marriage is a status"); State v. Austin, 234 S.E.2d 657, 662-63 (W. Va. 1977) ("The law has long recognized that while marriage is founded on contractual principles, it is a status which society, acting through the State, fosters and encourages.").

172. See supra notes 2-6 and accompanying text.

173. See BACHMAN \& SALTZMAN, supra note 1 , at 4 . In $31 \%$ of murders, the relationship between the victim and the murderer was not identified; thus the percentage of women murdered by their husbands or ex-husbands could be as high as $49 \%$. If, as is more likely, roughly $18 \%$ of the unreported relationships were husband-wife relationships, then about $27 \%$ of female victims of homicide were murdered by their husbands or ex-husbands. See id.

174. See id.

175. See S. REP. NO. 102-197, at 36 (1991).

176. See BACHMAN \& SALTZMAN, supra note 1 , at 4.

177. See supra text accompanying note 169. 
at how these laws changed and use Reva Siegel's work to argue that, notwithstanding these changes, marriage as constituted by modern laws continues, in many ways, to enforce a status regime, taking power away from women and giving that power to men.

The law of marriage as the nineteenth-century woman's rights movement knew it systematically subordinated women. Marriage was not merely a contract between two people; it also created a status relationship, one dealt with by the common-law doctrine of coverture. According to the law of coverture, as Blackstone famously wrote, "[b]y marriage, the husband and wife are one person in law: that is, the very being or legal existence of the woman is suspended during the marriage, or at least is incorporated and consolidated into that of the husband: under whose wing, protection, and cover, she performs every thing" ${ }^{178}$ At common law, a wife was "civilly dead" $;^{179}$ she had no right, for example, to bring tort actions or to make contracts on her own. ${ }^{180}$

This "civil death" extended to every aspect of a woman's life. When a woman married in the early nineteenth century, her personal property became her husband's property. He controlled any real estate she brought to the marriage. He owned all wages she earned from work outside the home. ${ }^{181}$ Nor did women have any rights to their household labor, for they did not have joint property rights in property or earnings acquired during the course of a marriage. ${ }^{182}$

Even more strikingly, a wife did not have the right to control her own body. At common law, a man was permitted to "chastise" his wife. Again, Blackstone:

The husband also (by the old law) might give his wife moderate correction. For, as he is to answer for her misbehaviour, the law thought it reasonable to intrust him with this power of restraining her, by domestic chastisement, in the same moderation that a man is allowed to correct his servants or children.... [T] he courts of

178. 1 WLLIAM BLACKSTONE, COMMENTARIES * 430 (foomote omitted).

179. ELIZABETH CADY STANTON ET AL., DECLARATION OF SENTIMENTS AND RESOLUTIONS AT THE FIRST WOMAN'S RIGHTS CONVENTION IN SENECA FALLS (1848), reprinted in PUBLIC WOMEN, supra note 38 , at 190, 191.

180. See 1 BLACKSTONE, supra note 178 , at *431.

181. See Linda E. Speth, The Married Women's Property Acts, 1839.1865: Reform. Reaction, or Revolution?, in 2 WOMEN AND THE LAW: A SOCLAL HISTORICAL PERSPECTIVE 69. 69 (D. Kelly Weisberg ed., 1982).

182. See Reva B. Siegel, Home as Work: The First Woman's Rights Claims Concerning Wives' Household Labor, 1850-1880, 103 Y ALE L.J. 1073. 1084-91 (1994) (discussing the lack of joint property rights and the great value of women's home-based labor in the nineteenth century). 
law will still permit a husband to restrain a wife of her liberty, in case of any gross misbehaviour. ${ }^{183}$

In the nineteenth century, ${ }^{184}$ marital rape was an oxymoron: Rape was, by definition, something that a man did to someone not his spouse. As Lord Chief Justice Matthew Hale proclaimed, "[T]he husband cannot be guilty of a rape committed by himself upon his lawful wife, for by their mutual matrimonial consent and contract the wife hath given up herself in this kind unto her husband, which she cannot retract." ${ }^{185}$ Without the ability to control when she had sex, a wife could not control when she became pregnant or how many children she would have. ${ }^{186}$

Each of these legal impediments has been transformed over the last 150 years. In the mid-1800s most states passed acts allowing married women to own property; eventually, all states passed such acts. ${ }^{187}$ The Supreme Court has held unconstitutional a Louisiana statute that gave a man, as "head and master" of property jointly owned with his wife, the right to dispose of that property without the wife's consent. ${ }^{188}$ The right of a husband to "chastise" his wife was out of favor even when Blackstone wrote, ${ }^{189}$ and was formally repudiated by the end of the $1870 \mathrm{~s} .{ }^{190}$ Changes in the marital-rape exemption were slower to come: It is only within the last twenty years that most states have modified their rape laws, ${ }^{191}$ and currently no state's laws include an absolute marital-rape exemption. ${ }^{192}$ But a closer look shows that these legal changes have not erased the unequal nature of marriage; to the contrary, it can be argued that the new forms of law regarding marriage, and the justifications for these new laws, serve only to reinforce marriage's unequal impact and implications.

Take, for example, the evolution of laws regarding women's right to their own work. Even though laws have changed to allow women the right

183. 1 BLACKSTONE, supra note 178 , at $* 432-33$ (footnotes omitted): see also Reva B. Siegel, "The Rule of Love": Wife Beating as Prerogative and Privacy, 105 YALE L.J. 2117. 212129 (1996).

184. And, indeed, well into the twentieth century. See infra text accompanying notes 191 192.

185. I Matthew Hale, The History of the Pleas of the Crown 629 (London. Sollom Emlyn 1736).

186. See, e.g., Siegel, supra note 182 , at 1105-06.

187. See Speth, supra note 181 , at 70 (stating that by the end of the Civil War. 29 states had passed acts permitting married women to own property).

188. See Kirchberg v. Feenstra, 450 U.S. 455,456 (1981).

189. See 1 BLACKSTONE, supra note 178 , at $* 433$ (" [W]ith us, in the politer reign of Charles the second, this power of correction began to be doubted: and a wife may now have security of the peace against her husband ...." (footnotes omitted)).

190. See Siegel, supra note 183, at 2129-30.

191. See Lisa Bernstein, Trends in Marital Rape Laws: Progress or Façade?, 2 UCLA WOMEN's L.J. 273, 273 (1992).

192. See Jennifer Gaffney, Note, Amending the Violence Against Women Act: Creating a Rebuttable Presumption of Gender Animus in Rape Cases, 6 J.L. \& POL'Y 247. 259 n.51 (1997). 
to the earnings from work outside the home, women still are unable to contract for compensation for the work they perform in the household..$^{193}$ As Reva Siegel argues, this bar on interspousal contracts for work performed within the home is "far from an antiquarian relic of a prior regime of status. Rather, it is the cornerstone of a new regime of status." ${ }^{19}$ Courts now refuse to enforce these contracts on the grounds that marital service is "presumed gratuitous," 195 and that there is a sphere into which courts may not intrude. ${ }^{196}$ This reasoning has made interspousal agreements about household labor "paradigmatically "private," 197 an area in which most couples would not even consider invoking the law. Thus work traditionally performed by women in marriages goes uncompensated, leaving many women "economically disempowered during the life of the marriage and impoverished at divorce." 198

Similarly, changes in the laws regarding "chastisement" and marital rape actually served to reinforce violence against women by translating the no-longer-acceptable language of marital unity into a more acceptable discourse about family privacy. ${ }^{199}$ Indeed, Chief Justice William Rehnquist drew on just this discourse when he criticized the Violence Against Women Act for potentially "involv[ing] the federal courts in a whole host of domestic relations disputes." ${ }^{200}$ Rehnquist conceived of domestic violence as a family matter, not a crime. As Siegel convincingly shows, reform movements do not necessarily erase subordination, but rather result in new justifications for that subordination that are more acceptable to society and thus perpetuate the subordination. ${ }^{201}$

To put it another way, facially neutral laws are not enough to exempt states, the creators of marriages, from responsibility, because the de facto reality of marriage encourages violence and subordination, even without explicit de jure enforcement of that violence and subordination. As Catharine MacKinnon explains in the context of judicial opinions, legal "neutrality" is meaningless in the face of real inequality: "From women's point of view, adjudications are already substantive; the view from nowhere

193. See Reva B. Siegel, The Modemization of Mariral Stanus Law: Adjudicating Wives' Rights to Earnings, I860-1930, 82 GEO. L.J. 2127, 2209 (1994) ("IN]o American court has ever enforced such an agreement.").

194. Id. at 2171 .

195. Id. at 2206 (citation omitted).

196. See id. at 2206-10.

197. Id. at 2209; see also id. at 2196-97 ("The principles cours developed at the turn of the century to justify the prohibition on interspousal contracts for domestic labor still govem such contracts today.").

198. Id at 2209.

199. See Siegel, supra note 183, at 2150-74.

200. William Rehnquist, Chief Justice's 1991 Year-End Report on the Federal Judiciary. THIRD BRANCH, Jan. 1992, at 1, 3, quoted in Siegel, supra note 183. at 2174.

201. See Reva B. Siegel, Why Equal Protection No Longer Protects: The Evolving Forms of Status-Enforcing State Action, 49 STAN. L REv. 1111,1113 (1997). 
already has content." ${ }^{202}$ In other words, if the law has created a de facto system of inequality, a switch to de jure neutrality will not erase the damage; it will simply stabilize the de facto inequality. The history and reality of marriage are such that even neutrally framed laws (that is, the elimination of most laws that facially favor men in marriage) cannot erase subordination and violence engendered by marriage; because the state continues to create and support marriage as an institution, it is complicit in the resulting damage, notwithstanding the facially neutral laws it provides.

Finally, it is important to be aware of the extent to which the law has not changed and continues explicitly to protect husbands who assault and rape their wives. In many states, marital rape is still treated as a lesser crime than other kinds of rape. For example, the punishment for marital rape may be less stringent; in some states, a wife may prosecute a husband for rape only if he uses force; and acts that would be crimes outside of marriage (such as sexual battery) may not be considered crimes if committed within marriage. ${ }^{203}$ And the Model Penal Code continues to define rape as a crime committed by "[a] male who has sexual intercourse with a female not his wife." 204

In short, marriage between a man and a woman partakes of a "cultural construct... of marital roles, obligations, and identities constituted by an axis of subordination." ${ }^{205}$ Marital life is weighted down with "the illiberal, nonegalitarian, and unfree heritage of [marriage's] deeply patriarchal past." ${ }^{206}$ Marriage as it exists now is more than a contractual relationship between two people: It is an ordering of social relations, an ordering that places the woman squarely at the bottom, subject to the "stony, ancient concept of ownership of women by men." ${ }^{207}$ Such an ordering affects unmarried as well as married people, for every woman is a potential or an actual wife, and every man knows that people like him have owned and dominated people like her through an institution that continues to exist

202. Catharine A. MacKinnon, TOWARD a Feminist TheORY OF THE STATE 167 (1989): see also Siegel, supra note 183, at 2119 (introducing the term "preservation through transformation" in the context of marriage law). Siegel suggests that the fact that "proving discriminatory purpose [is] now ... required in all cases challenging [under the Equal Protection Clause] facially neutral state action having a disparate impact on protected classes" is an example of preservation through transformation. Siegel, supra note 201, at 1134 .

203. See Gaffney, supra note 192, at 259 n.51. For more on marital rape, see, for example. Lisa Dawgert Waggoner, New Mexico Joins the Twentieth Century: The Repeal of the Marital Rape Exception, 22 N.M. L. REv. 551 (1992); and Robin West, Equality Theory. Marital Rupe. and the Promise of the Fourteenth Amendment, 42 FLA. L. REV. 45 (1990).

204. MODEL PENAL CODE $§ 213.1$ (1) (1998).

205. Robin West, Universalism, Liberal Theory, and the Problem of Gay Marriage, 25 FLA. ST. U. L. REV. 705, 727 (1998).

206. Id.

207. Mary C. Dunlap, The Lesbian and Gay Marriage Debate: A Microcosm of Our Hopes and Troubles in the Nineties, 1 LAW \& SEXUALITY 63, 70 (1991). 
today. ${ }^{208}$ Marriage, a state creation, continues to contribute to the subordination of women even in its current facially neutral form.

The idea of marriage as state action is in the tradition of the Court's finding state action where none is obvious in order to remedy discrimination. The state does not simply sit by and watch as violent marriages persist; ${ }^{209}$ rather, states actively create the institution of marriage. Moreover, the Court has repeatedly emphasized the context-specific nature of the state action inquiry. ${ }^{210}$ As I have shown, when marriage is viewed in its historical and cultural context, it is revealed to be a "co-operative force[" 211 that leads to a culture of violence against women, which in turn interferes with women's political citizenship. ${ }^{212}$ Congress may therefore act under the Nineteenth Amendment to remedy the private components of such violence. ${ }^{213}$

\section{CONCLUSION: THE PROMISE OF THE NINETEENTH AMENDMENT}

The Nineteenth Amendment is notable for what it did not accomplish. It did not lead to the establishment of a political party for women; ${ }^{214}$ it was

208. See supra notes $76-85$ and accompanying text.

209. The situation is thus quite unlike that in DeShaney v. Winnebago County Department of Social Services, 489 U.S. 189 (1989), in which the Court found that the state could not be held responsible under the Fourteenth Amendment for not intervening when it knew that a child was being brutally beaten by his father, since the failure to act did not constitute state action: "While the State may have been aware of the dangers that Joshua faced in the free world, is played no porr in their creation, nor did it do anything to render him any more vulnerable to them." Id. at 201 (emphasis added). In contrast, the State does play a part in the creation of marriage; indeed, the state alone can create a marriage. See supra notes 160-167 and accompanying text.

210. See, e.g., Burton v. Wilmington Parking Auth., 365 U.S. 715. 722 (1961) ("Onily by sifting facts and weighing circumstances can the nonobvious involvement of the State in private conduct be attributed its true significance."). A number of cases cite Burton for this proposition. including, for example, Gilmore v. City of Montgomen. 417 U.S. 556. 574 (1974); and Evans v. Newton, 382 U.S. 296, 299-300 (1966).

211. See supra text accompanying note 152 .

212. See supra Part III.

213. Moreover, because the relevant state action is marriage, not the unequal enforcement of criminal laws, VAWA does not threaten principles of federalism. as alleged by the only circuit court to hold the civil rights provision of VAWA unconstitutional. See Brzonkala v. Virginia Polytechnic Inst. \& State Univ., 169 F.3d 820. 888 (4th Cir. 1999) (en banc) (stating that if VAWA is allowed on the grounds that crimes against women are not properly prosecuted and punished because of state gender bias, "the very same or similar legislative record of section 13891 could support an analogous finding that all state criminal laws are infused with gender bias," leading to "a general federal criminal code to replicate or preempt the existing criminal laws of the fifty States in order to root out any such bias"), cert. granted, 68 U.S.L.WV. 3021 (U.S. Sept. 28, 1999) (Nos. 99-5, 99-29). Instead, when Congress addressed the private component of the constitutional violation (that is, by allowing an action against a violent privale party). instead of directly addressing the state action (by, say, outlawing marriage). Congress displayed the utmost respect for the fact that "[t]he power of the States [as opposed to the federal government] over marriage and divorce is . . complete except as limited by specific constitutional provisions." Boddie v. Connecticut, 401 U.S. 371, 385 (1971) (Douglas, J., concurring in the result).

214. See, e.g., ELEANOR FLEXNER, CENTURY OF STRUGGLE 338 (rev. ed. 1975). 
not taken up by the Supreme Court to justify jury service for women; ${ }^{215}$ it did not eliminate gender subordination. ${ }^{216}$ Indeed, woman suffrage has been described as "the biggest non-event in our electoral history." ${ }^{17}$ However, the potential of the Nineteenth Amendment has not yet been tapped. ${ }^{218}$ In particular, Congress's role in enforcing the Nineteenth Amendment has not received sufficient attention. ${ }^{219}$ Just as the Civil War amendments were not expected to be self-enforcing, ${ }^{220}$ so too congressional action is needed to realize fully the meaning of the Nineteenth Amendment. The problems of gender subordination that prevent women from being full, political citizens are too deeply rooted to be addressed only by the courts. Congress has the power to take the steps needed to make good the promise of the Nineteenth Amendment, and the Violence Against Women Act is one such step.

215. See, e.g., J.E.B. v. Alabama ex rel. T.B., 511 U.S. 127 (1994) (using the Equal Protection Clause to justify a prohibition of discrimination on the basis of gender in the exercise of peremptory challenges). See generally Amar, Jury Service, supra note 29 (discussing the link between voting and jury service); Jennifer K. Brown, Note. The Nineteenth Amendment and Women's Equality, 102 YALE L.J. 2175 (1993) (discussing the use of Nineteenth Amendment by state courts as a basis for requiring that women be allowed to serve on juries).

216. See, e.g., Lind, supra note 27 , at 210-11.

217. SHKLAR, supra note 30 , at $60-61$. She explains that "because women had adopted the dominant attitudes of their time and place so completely, their final victory led to no noticeable political change at all... Those members of the suffrage movement who had seen it as an instrument of social transformation were wholly unrealistic." $/ d$.

218. See, e.g., Brown, supra note 215, at 2204 ("The Nineteenth Amendment was the product of the revolutionary idea that women have equal status in a democracy. As a nation, we are still pursuing this vision of equality, yet we have allowed this constitutional enactment only a paltry existence. ... Perhaps there is yet more this women's amendment to the Constitution can accomplish ...." (citation omitted)).

219. See, e.g., Lind, supra note 27, at 193-216 (focusing on the Supreme Court's role in "maintain[ing] and preserv[ing] . . the status quo" after passage of the Nineteenth Amendment); Brown, supra note 215 , passim (discussing the role of courts, particularly state courts, in giving meaning to the Nineteenth Amendment).

220. See Ex parte Virginia, 100 U.S. 339, 345 (1880) ("Some legislation is contemplated to make the [Thirteenth and Fourteenth] amendments fully effective."). 